Yasmina Saleh - Mahmoud Kandeel - Hassan Bekkali - Ali Lateef - Brahim Dargouthi Essam M. Al- Jassim

\title{
Flash Fiction from North Africa
}

Yasmina Saleh - Algeria

\section{Bloodbath}

At least five or six of them, maybe even more, had overrun his house and family. He was not a politician, an inciter of dissent, nor a troublesome writer; he was a decent citizen. Yet they permeated his little dreams and reluctant joys.

The darkness and gloominess of the Algerian night increased after the first shot was fired; the family was overcome with unspeakable dread. Another scene of horrible confusion, terror, and carnage ensued.

Mahmoud Kandeel - Egypt

\section{Birth}

Despite the tombstones surrounding her, the place felt empty. The cemetery stood still but for her nervous figure, sitting and fidgeting beside a green, rusted dumpster. Agitated, the woman stuck her right hand inside her blouse and fiddled with something unseen, as though desperately searching for something lost.

"Look, she's caressing her breasts," my companion whispered with a snicker.

I didn't join in. The woman appeared to be emerging from the depths of sorrow, perhaps having recently suffered a profound, secret tragedy. 
As she continued moving her hand beneath her blouse, a profusion of sweat slid from her forehead and down her face before dripping off her chin. She released loud, pent-up groans, as a woman in the throes of labor, determined to extricate the foreign object.

Minutes passed before her agonies lessened, then ceased. She finally withdrew her blood-covered hand holding a still-beating heart. With a faded, bitter smile, she looked around to ensure no one was watching before tossing the heart into the trash.

Ali Lateef - Libya

\section{The Belle and Gazelle Statue}

It was eight years ago, before the statue of Belle and Gazelle was stolen from the heart of the city. She was the last female nude left in Tripoli.

I was in the car with my father, a traditional man from Alkidwa, which was a rural area some forty kilometers from Tripoli. He'd led a tough life but had become a physician, although he told me he'd always wanted to be a pilot. He used to turn to me whenever he saw a plane in the sky and say, "Look at that plane. See her? Isn't she gorgeous?"

I remember the shape of his narrow black eyes and the dark pockets beneath them. I only understood that state later on, when I experienced the same emotions he had been feeling. A shattered dream and the beginning of a nightmare had appeared, only slightly before the end.

During my teenage years, I used to spend many hours sitting in Gazelle Park with my friends. We played the guitar and sang songs we wouldn't understand until we were much older. My voice was bad, but they lied to me and said it was beautiful. The park was next to and named after the statue of Belle and Gazelle and was the gathering spot for whores, drug addicts, and the homeless human scum, so they said then and still say today.

But scum can fall in love too, and that was what they didn't understand. I kissed my first girlfriend in 
that park; I touched her breasts for the first time in that park. She once sang with me, her voice stunning and soft. My friends said she was a whore, but I didn't care.

"Your body is like Belle, and your soul like Gazelle," I once told her. When I think of my words these days, I laugh; they were so clichéd and vulgar. She chuckled, a faint blush making her cheeks look like unripe plums. Her eyes were tinted with the color of fallen autumn leaves and shone with ecstasy. Her fully grown breasts were like a virgin making love to a fiery shooting star, hurtling its way toward Earth.

I don't know why, but every time I remember her these days, I remember my father and the statue of Belle and Gazelle.

One day, he and I drove by it. He was supposed to let me off in front of the Dawa Mosque in Algiers Square, just a few minutes' walk from the park. Before I got out, though, he told me a story - one I still remember to this day. "One day, at the first light of dawn, a man dressed the naked statue in his wife's red brassiere and ran away. The red bra stayed on the statue till noon; no one dared take it away. You should've seen the faces of people passing by."

Then my father started laughing, and I still remember its specific resounding quality. It wasn't weak, and despite his pallid face, tight eyes, and tobacco-stained lips, he looked handsome, like one of Michelangelo's statues, or a heroic pilot.

The statue of Belle and Gazelle was stolen almost a year ago. At first, a group of fundamentalist terrorists shot at it; months later, a local militia stole it. The park became just another in Tripoli - a space with no flowers and the scattered, happy memories of the scum who'd spent time there. My first girlfriend and her family became refugees after the revolution. Her father had committed heinous crimes as part of the former regime. It was the last I ever heard of her, and that was years ago. But on the day the statue was taken, when my father returned home grouchy and miserable, I recalled once again her laughing aloud at how I used to cuddle her, mumbling those clichéd and vulgar words. I visualized her crying about her current situation. Then I remembered how I'd walked beside the statue of Belle and Gazelle on my way to her. I was scum, but good scum, able to at least smile when meeting beauty. 
Published with permission from Arabian Stories.

Hassan Bekkali - Morocco

\section{A Potential Client}

Spanish guitar tones seep through the walls and floor of the café. She sits on her usual seat, waiting for a potential client. One hand fondles a blond, filtered cigarette while the other scrolls through the numbers on her cell phone. She keeps an eye on the stream of people moving along the street outside. The traffic is light compared to peak hours, as bodies loom large amid the sounds of labored breaths and diminish as the passersby move along the boulevard.

A young man, handsome and clean-shaven, advances toward the café at a steady pace. She observes him keenly.

Without a doubt, he's a naïve, well-to-do customer.

She extinguishes her cigarette in the ashtray and exchanges a complicit smile with the waiter. The handsome, young man peers through the glass façade of the café. She's ready and prepared to play her role.

He gives one last gaze, and then a violent explosion that seems to spread outward from him disperses panic in the vicinity.

Brahim Dargouthi - Tunisia

\section{The Ashes of Hell}

When I returned from the cemetery that bleak and fateful morning, I tapped on my mother's door softly as if she were still lying asleep on her sickbed. I entered on tiptoe and went straight to her antique, oak coffer, decorated with all the colors of the rainbow. 
Her distinct fragrance still hung in the air. I stared at the neatly made bed and whispered, "Forgive me, my dear, if I have to violate your secrets today."

Taking me by surprise, she answered, "The coffer's key is under the pillow, my darling."

The scent of heaven immediately struck me as soon as I turned the key in the lock and slowly raised the paneled top. Some small items were neatly arranged inside: sandalwood, amber, small bottles of rosewater, a yellow quince, a small book of dhikr the size of a hand, three new candles, and a fourth that was half melted.

My mother had always hated power switches; to her, they resembled the fangs of rabid dogs. Alongside the coffer's contents were sticks of incense and coins hailing from the period of the French protectorate of Tunisia. They were pierced in the middle, and the inscriptions showed they had been minted during the reign of Nasser Pasha, the Bey of Tunisia and its outposts. I also found some letters my father had sent from France during World War II, before he met his death in a concentration camp that the Germans had constructed in honor of the Jews.

My father, like all Muslims, was circumcised, and Adolf Hitler's soldiers had murdered him, believing he was one of God's chosen people. Reciting the Shahada, "There is no God but Allah, and that Muhammad is the Messenger of Allah," had not benefited him personally. All languages in those camps sounded the same to the Germans, and they were hell-bent on perceiving all the circumcised as Jewish.

My mother never ceased cursing the world's Jews, and I had to listen to that story repeatedly from the age of ten. Every single time, that idea made me laugh uproariously, which only aggravated her anger. Then she'd stop reviling the Jews and start cursing my father, since he was the one who'd failed to disguise his genitals from the Germans' eyes. A petty scrap of foreskin was the sole reason behind his death - the very skin the Jews had taught our desert ancestors to cut from their sons' bodies. Our people had failed to realize that Jacob's cousins, who joined them in those camps in France, would make those foreskins into ropes to hang them.

In her later years, once she finished her story, my mother would laugh and then say, "The late 
President Anwar Sadat was reconciled with that goddamned Menachem Begin because his Mossad informed him Mr. Sadat was circumcised, just like the Jews."

Her expression would grow tender as she gently tapped my shoulder and continued, "Son, I never thought of getting married again after your father died. My heart became haunted by the ashes of hell after his bed became colder than the desert winter..."

From that moment on, I hid my mother's secrets, large and small, in my heart and closed its seven doors, one after the other. I imagined her smiling in the grave.

"I won't sell your wooden chest, decorated in rainbow shades," I told her.

Spring grew over her grave.

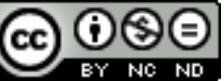

Creative Commons Attribution-NonCommercial-NoDerivatives 4.0 International License 